\title{
Mesenchymal stroma cells (MSCs) in Regenerative Medicine: an update
}

\author{
Axel R. Zander \\ University of Hamburg, Germany \\ Prof. Dr. Axel R. Zander, University of Hamburg, 20246, \\ E-mail: arzzander@aol.de
} Hamburg, Germany

Citation: Zander AR. Mesenchymal stroma cells (MSCs) in regenerative medicine: an update. Cell Ther Transplant 2019; 8(4): 15-18.

\section{Summary}

Mesenchymal stroma cells (MSCs) have anti-inflammatory, anti-apoptotic and immunomodulating properties, and they have, therefore, been explored in the treatment of autoimmune and chronic inflammatory diseases during the last two decades. MSCs have reached regulatory approval in several countries for the treatment of Acute Graft-versus-Host Disease and for Crohn's disease. Results in several other diseases like Lupus, Multiple Sclerosis, Amyotrophic Lateral Sclerosis, and Spinal cord injury look promising.
Uncritical, direct to consumer sales of unapproved stem cell treatments by private entrepreneurs cloud the field of MSC research and jeopardize the establishment of MSC treatment in the armamentarium of Medicine. Several more years are necessary for a full evaluation of this new treatment modality in several indications.

\section{Keywords}

Mesenchymal stromal cells, immune effects, medical applications.

\section{Introduction}

Alexander Friedenstein is considered the founder of the mesenchymal stem cell concept. He described fibroblasts like clonogenic cells, forming colonies, named by him CFU-F. The MSCs are multi-potential, and differentiate into osteoblasts, chondrocytes and adipocytes [1] and support hematopoiesis. Alexander Friedenstein himself refers to Alexander Maximov, who first described stromal-hematopoietic interrelationship, hypothesizing that committed hematopoietic precursors descend from the hematopoietic stem cells, due to local impacts generated by marrow stroma, leading to hematopoietic differentiation [2, 3]. These fibroblast like clonogenic cells have been named by Caplan mesenchymal stem cells [4]. These CFU-F have been shown to be negative for the markers CD34, CD45, CD14, MHCII and positive for the markers CD90, CD105, MHCI an CD73. These cells can be induced and differentiated to adipocytes, documented by staining of lipid vacuols with sudan red, into osteoblasts, which can be documented by staining of calcium deposits with silver nitrate and into chondroblasts, documented by staining of proteoglycanes with alcian blue. These precursors can be propagated millionfold in liquid culture $[5,6,7]$.
MSCs are immunoprivileged cells and possess immunomodulatory properties, modulating all populations of the innate and adaptive immune system [8]. MSC decrease proliferation cytotoxicity and interferon- $\gamma$ production by NK cells, diminish proliferation of B cells and their differentiation to plasma cells. They decrease proliferation and CTL formation as well as interferon gamma production of T-Cells, increase regulatory $\mathrm{T}$-Cells and decrease differentiation, maturation and activation of dendritic cells [8]. MHC suppress T-cell proliferation and TH1 specific cytokine secretion [9].

There has been an immense interest in clinical application of MSCs for several reasons:

1. There is no need for complicated donor search. MSC can be given beyond the MHC barrier. That leads to easy availability.

2. One donation provides cells for many treatments, which makes this approach inexpensive.

3. No major side effects have been reported from MSC infusion. MSC treatment is considered to be safe.

The mechanism of action of MSC has been explored in several preclinical systems, like acute kidney injury, where MSC therapy augments expression of anti-apoptotic BCL-2 
and inhibits that of pro-inflammatory genes, like eNOS. It inhibits expression of pro-inflammatory genes (IL1-beta, TNF-alpha, IFN-gamma) and it increases the expression of anti-inflammatory IL-10 [10, 11, 12]. MSC therapy has been further explored in models for radiation injury, where it rescued mice after supralethal irradiation [13]. In this model MSC treatment leads to an increased expression of genes related to detoxification, cell metabolism, cell motility, antiinflammation and anti-apoptosis, as well as a decreased expression of genes associated with toxification, inflammation and apoptosis [13]. Based on several studies in kidney, heart, radioprotection and graft-versus-host disease, it could be shown that MSCs are anti-inflammatory, anti-apoptotic, angiogenic and mitogenic $[14,15,16]$.

The first area of MSC therapy was acute graft-versus-host disease, where Katharina Le Blanc could show effectiveness in steroid resistant acute graft-versus-host disease in a proof of concept study [17], followed by a multi-center European study including 55 patients, leading to complete response in 30 patients and to some improvement in 9, which lead to lower transplant related mortality in responding patients [18]. The company Osiris Therapeutics carried out a phase 3 trial in adults and children with GvHD, in which only the subset of children showed a significant response to MSCs $[19,20]$. Osiris did not obtain licenses for MSC treatment of GvHD in the United States and Europe, following the study. Health Canada gave a notice of compliance with conditions (hightened post-market surveillance), but so far no approval. In Japan, MSCs can be marketed (Tem-cell) for acute graftversus-host disease [21]. In Europe a new attempt in steroide resistant GvHD treatment with standardized MSC from several donors, is carried out in a multi-center study. The preliminary reports appear very promising [22]

210 studies are listed as completed under clinicaltrials.gov. Major entities include are as follows: rheumatic arthritis/osteoarthrtis $(n=12)$; amyotrophic lateral sclerosis $(n=9)$; graftversus-host disease $(n=8)$; multiple sclerosis $(n=7)$; diabetes $(n=7)$; Crohn's disease $(n=6)$; myocardial infarction $(n=5)$; spinal cord injury $(n=4)$.

The general overview of all these studies, reveals some activity, but not enough for licensing in all countries, in steroid resistant GvHD, some activity in Crohn's disease, where several randomized studies could show that a reduction of steroid dose is possible, following MSC treatment [23, 24]. Encouraging findings in spinal cord injury, where improved sensory and bladder function were noted, but no improvement in motor function and the treatment was proven to be safe [25]. In Amyotrophic-Lateral-Sklerosis (ALS), a disease with very few treatment options, several studies showed slower progression of disease in the treated group, but larger studies are needed $[26,27]$.

There are several encouraging studies in MS, a large randomized study has been initiated by Andrea Uccelli and several European groups [28].

In Lupus several studies showed improved disease activity, but a large-scale validation is needed $[29,30]$. The results of the studies in Diabetes mellitus are less encouraging, even though there has been some improvement in DMT1 $[31,32]$.
Results in arthritis show inconsistent results and in heart disease large randomized studies showed no long-term benefit [33-37].

The field of MSC is under attack from two directions. Several studies have shown that the phenotype of MSC in vitro does not reflect cell identity and function. Stromal cells from bone marrow, muscle, peritoneum and cord blood have been isolated and the gene expression profiles clearly separated by origin of cells and MSCs from different sources have radically different, differentiation properties [38], leading to the editorial "Clear up the Stem Cell mess", by Sipp Douglas et al. [39]. He states that the confusion about mesenchyme stem cells is making it easier for people to sell unproven treatments. The problem lies in the name mesenchymal stem cell. Caplan, who coined the term mesenchymal stem cell, recommended the more correct term of "Medicinal Signaling Cells". Other investigators use the term Mesenchymal Stroma Cell, which might suffice to get these cells out of the hyped stem cell theater.

The excellent sales argument for MSC - no complicated donor search, one donation for many treatments and the safety of the infusion, led to an explosion of unapproved stem cell treatments in USA, Australia and Japan, with direct to consumer marketing. In 2016 there were 351 US companies selling putative stem cell treatments, mostly MSCs, directly to the consumer [39]. To dispel the MSC myth one should stop bunching multiple cell types, under one catchall phrase. Clinical trial registries, as well as editors and reviewers should be more critical. One should watch for well designed and well described clinical studies in regenerative medicine. Regulators should stop commercial clinics from selling unproven treatments whenever possible. Physicians should discourage their patients from receiving unproven stem cell therapies. Overall one should keep in mind, not to pour out the baby with the bath water: it will take more time to firmly establish MSC treatment in Regenerative Medicine.

\section{Acknowledgement}

Thanks to Andrea Zander for her assistance in the preparation of the manuscript.

\section{Conflict of interest}

None reported.

\section{References}

1. Friedenstein AJ, Chailakhyan RK, Latsinik NV, Panasyuk AF, Keiliss-Borok IV. (). Stromal cells responsible for trabsferring the microenvironment of the hemopoietic tissues. Cloning in vitro and retransplantation in vivo. Transplantation. 1974; 17:331-340.

2. Maximov AA. Über experimentelle Erzeugung von Knochenmarksgewebe. Anat Anz. 1906; 28: 24-38.

3. Afanasiev BV, Elstner E, Zander AR. A. Friedenstein, founder of the mesenchymal stem cell concept. Cell Ther Transplant. 2009; 1(3): 35-38. 
4. Caplan AI. Mesenchymal stem cells. J Orthop Res. 1991; 9:641-650

5. Porcellini A. Regenerative medicine: a review. Rev Bras Hematol Hemoter. 2009;31 (Suppl. 2). 31:63-66. DOI:10.1590/S1516-84842009000800017.

6. Bunnell BA, Flaat M, Gagliardi C, Patel B, Ripoll C. Adipose-derived stem cells: Isolation, expansion and differentiation. Methods. Methods in Stem Cell Res. 2008; 45(2):115120.

7. Lange C, Schroeder J, Stute N, Lioznov MV, Zander AR. High-potential human mesenchymal stem cells. Stem Cells Dev. 2005;14(1):70-80.

8. Nauta AJ, Fibbe WE. Immunomodulatory properties of mesenchymal stromal cells. Blood. 2007;110:3499-3506.

9. Fang L, Lange C, Engel M, Zander A, Fehse B. Sensitive balance of suppressing and activating effects of mesenchymal stem cells on T-cell proliferation. Transplantation. 2006;82(10):1370-1373.

10. Tögel F, Westenfelder C. Treatment of acute kidney injury with allogeneic mesenchymal stem cells: preclinical and initial clinical data. In: Regenerative Nephrology (Ed. M. Goligorsky), Elsevier, 2011. pp. 315-339.

11. Tögel F, Westenfelder C: Mesenchymal stem cells: a new therapeutic tool for AKI. Nat Rev Nephrol. 2010; 6(3):179183, DOI: 10.1038/nrneph.2009.229.

12. Tögel F, Westenfelder C: The role of multipotent marrow stromal cells (MSCs) in tissue regeneration. Organogenesis.2011; 7(2):96-100, DOI: 10.4161/org.7. 2. 15781.

13. Lange C, Brunswig-Spickenheie B, Cappallo-Obermann H, Eggert K, Gehling UM, Rudolph C, Schlegelberger B, Cornils K, Zustin J, Spiess AN, Zander AR. PLos One. 2011;6(1):e14486. Doi: 10.1089/scd.2009.0494.

14. Krause K, Fehse B, Jaquet K, Lange C, Kyriazis K, Boczor S, Zander A, Kuck K. Analysis of progenitor cell mobilization and erythropoietin plasma levels in patients with acute myocardial infarction. Exp Clin Cardiol. 2005;10(2):104-107.

15. Wang S, Qu X, Zhao RS. Clinical applications of mesenchymal stem cells. J Hematol Oncol. 2012. 5:19. DOI:10.1186/1756-8722-5-19.

16. Zander AR, Lange C, Westenfelder C. Mesenchymal stromal cells: main factor or helper in regenerative medicine? Kidney Int. 2011; 1(3 Suppl):74-76.

17. Le Blanc K, Rasmussen I, Sundberg B, Gotherstorm C, Hassan M, Uzunel M et al. Treatment of severe acute graftversus-host-disease with third-party haploidentical mesenchymal stem cells. Lancet. 200;363:1439-1441.

18. Le Blanc K, Frassoni F, Ball L, Locatelli F, Roelofs H, Lewis I, Lanino E, Sundberg B, Bernardo ME, Remberger M, Dini G, Egeler M, Bacigalupo A, Fibbe W, Ringden O et al. Mesenchymal stem cells for treatment of steroid-resistant, severe, acute graft-versus-host disease: a phase II study. Lancet . 2008; 371,1579-1586.

19. Martin PJ Uberti JP, Soiffer RJ, Klingermann H, Waller EK, Daly AS, Herrmann RP, Kebriaei P. Prochymal improves response rates in patients with steroid-refractory, acute GvHD: results of a randomized, placebo-controlled, multicenter Phase III trial in GvHD. Biol Blood Marrow Transplant. 2010;16: S169-S170.

20. Kurtzberg J, Prasad V, Grimley M, Horn B, Carpenter P, Jacobsohn D, Prochop S. Allogeneic human mesenchymal stem cell therapy $\left(\right.$ Prochymal $^{\oplus}$ ) as a rescue agent for severe treatment resistant GVHD in pediatric patients. Biol. Blood Marrow Transplant. 2010; 16: S169.

21. Hara A, Sato D, Sahara Y. New governmental regulatory system for stem cell-based therapies in Japan. Ther Innov Regul Sci. 2014; 48:681-688.

22. Bader P. Effective treatment of steroid and therapy-refractory acute graft-versus-host disease with a novel mesenchymal stromal cell product (MSC-FFM). Bone Marrow Transplant. 2018; 53:852-862.

23. Panés J, García-Olmo D, Van Assche G, Colombel JF, Reinisch W, Baumgart DC, Dignass A, Nachury M, Ferrante M, Kazemi-Shirazi L, Grimaud JC, de la Portilla F, Goldin E, Richard MP, Leselbaum A ,Danese S; ADMIRE CD Study Group Collaborators. Expanded allogeneic adipose-derived mesenchymal stem cells (Cx601) for complex perianal fistulas in Crohn's disease: a phase 3 randomized, double-blind controlled trial. Lancet 2016; 388:1281-1290.

24. Panes J., García-Olmo D, Van Assche G, Colombel JF, Reinisch W, Baumgart DC, Dignass A, Nachury M, Ferrante M, Kazemi-Shirazi L, Grimaud JC, de la Portilla F, Goldin E, Richard MP, Diez MC, Tagarro I, Leselbaum A, Danese S;ADMIRE CD Study Group Collaborators. Long-term efficacy and safety of stem cell therapy (Cx601) for complex perianal fistulas in patients with Crohn's disease. Gastroenterology. 2018; 154: 1334-1342 e4.

25. Cofano F, Boido M, Monticelli M, Zenga F, Ducati A, Vercelli A, Garbossa D. Mesenchymal stem cells for spinal cord injury: current options. Int J Mol Sci. 2019; 20(11). pii: E2698.

26. Gugliandolo A, Bramanti P, Mazzon E. Mesenchymal stem cells: a potential therapeutic approach for amyotriphic lateral sclerosis. Stem Cells Int. 2019; 2019:3675627.

27. Oh KW, Noh MY, Kwon MS, Kim HY, Oh SI, Park J, Kim HJ, Ki CS, Kim SH. Repeated intrathecal mesenchymal stem cells for amyotrophic lateral sclerosis. Ann Neurol. 2018;84(3):361-373.

28. Uccelli A, Laroni A, Brundin L, Clanet M, Fernandez O, Nabavi SM, Muraro PA, Oliveri RS, Radue EW, Sellner J, Soelberg Sorensen P, Sormani MP, Wuerfel JT, Battaglia MA, Freedman MS; MESEMS study group. Mesenchymal stem cells for multiple sclerosis (MESEMS): a randomized, double blind, cross-over phase I/II clinical trial with autologous mesenchymal stem cells for therapy of multiple sclerosis“. Trials. 2019, May 9; 20(1):263. DOI 10.1186/s13063-0193346-z.

29. Deng D, Zhang P, Guo Y, Lim TO. A randomized double-blind placebo-controlled trial of allogeneic umbilical cord-derived mesenchymal stem cell for lupus nephritis“. Ann Rheum Dis. 2017;76(8):1436-1439. 
30. Cras A. Update on mesenchymal stem cell-based therapy in lupus and scleroderma. Arthritis Res Ther. 2015 Nov. 3; 17:301.

31. Zang L, Hao H, Liu J, Li Y, Han W, Mu Y. Mesenchymal stem cell therapy in type 2 diabetes mellitus. Diabetol Metab Syndr. 2017 May 15;9:36.

32. Moreira A, Kahlenberg S, Hornsby P. Therapeutic potential of mesenchymal stem cells for diabetes. J Mol Endocrinol. 2017; 59(3):R109-R120.

33. Liu L, Wong CW, Han M, Farhoodi HP, Liu G, Liu Y, Liao W, Zhao W. Meta-analysis of preclinical studies of mesenchymal stromal cells to treat rheumatoid arthritis. EBioMedicine. 2019 Sep; 47: 563-577. DOI: 10.1016/j.ebiom.2019.08.073.

34. Fan Yang, Yang Li. Effects of mesenchymal stem cells in autoimmune arthritis. Eur Med J. 2018 ;3 (4):130-137.

35. Steinhoff G, Nesteruk J, Wolfien M, Große J, Ruch U, Vasudevan P, Müller P. Stem cells and heart disease - Brake or accelerator? Adv Drug Deliv Rev. 2017;120:2-24. DOI: 10.1016/j.addr.2017.10.007.
36. Lalu MM, Mazzarello S, Zlepnig J, Dong YY, Montroy J, McIntyre L, Devereaux PJ, Stewart DJ. Safety and efficacy of adult stem cell therapy for acute myocardial infarction and ischemic heart failure (SafeCell Heart): a systematic review and meta-analysis. Stem Cells Transl Med; 7(12): 857-866.

37. Blau HM, Daley GQ. Stem cells in the treatment of disease. New Engl J Med. 2019; 308:1748-1760. DOI: 10.1056/ NEJMra1716145.

38. Sacchetti B, Funari A, Remoli C, Giannicola G, Kogler G, Liedtke S, Cossu G, Serafini M, Sampaolesi M, Tagliafico E, Tenedini E, Saggio I, Robey PG, Riminucci M, Bianco P. No identical mesenchymal stem cells at different times and sites: human committed progenitors of distinct origin and differentiation potential are incorporated as adventitial cells in microvessels. Stem Cell Rep. 2016; 6(6): 897-913.

39. Sipp D, Robey PG, Turner L. Clear up this stem-cell mess. Nature. 2018; 561(7724): 455-457.

\title{
Мезенхимные стромальные клетки в регенеративной медицине: обновленная версия
}

\author{
Аксель Р. Цандер \\ Гамбургский университет, Гамбург, Германия
}

\section{Резюме}

Мезенхимные стромальные клетки (МСК) проявляют противовоспалительные, анти-апоптотические и иммуномодулирующие свойства. Поэтому их исследовали на предмет лечения аутоиммунных и хронических воспалительных заболеваний на протяжении последних двух десятилетий. МСК получили одобрение надзорных органов в нескольких странах на лечение ими острой реакции «трансплантат против хозяина» и болезни Крона. Обещающие результаты получены при их применении для лечения некоторых других болезней, таких, как системная красная волчанка, множественный склероз, амиотрофиче- ский боковой склероз и при травмах спинного мозга. При некритичном подходе прямая продажа частными предпринимателями неразрешенных стволовых клеток для лечения вносит беспорядок в область исследований МСК и угрожают внедрению МСК в арсенал медицинских методов. Необходимы еще несколько лет для полной оценки этого нового подхода к лечению по нескольким показаниям.

\section{Ключевые слова}

Мезенхимные стромальные клетки, иммунные эффекты, медицинское применение. 